\title{
UJI AKTIVITAS ANTIBAKTERI EKSTRAK ETANOL DAUN KEMANGI (Ocimum basilicum L.) TERHADAP BAKTERI Streptococcus mutans
}

\author{
Aminah. S ${ }^{1}$, Rosa Aldora Purba ${ }^{2}$, Novidawati Boru \\ Situmorang ${ }^{3}$, Romauli Anna Teresia Marbun ${ }^{4}$ \\ Institut Kesehatan Medistra Lubuk Pakam, Jalan Sudirman No.38 \\ Lubuk Pakam \\ e-mail: syarifuddinami6@gmail.com
}

DOI : https://doi.org/10.35451/jfm.v2i2.368

\begin{abstract}
:
Basil leaf (Ocimum basilicum L.) is one of the most accessible natural plant in Asia such as Indonesia. Basil leaf vegetation contains a lot of flavonoid compounds and essential oils that have the effect as antibacterial because it can inhibit the growth of bacteria Streptococcus mutans cause dental caries. Streptococcus mutans is a round gram-positive bacteria that typically form pairs or chains during its growth. The purpose of this research is to know the antibacterial effectivity of ethanol extract of basil leaves (Ocimum basilicum L.) on the growth of Streptococcus mutans bacteria.This research was conducted with laboratory experimental research method. Basil lean ethanol extract was prepared by using maseration extraction method. The method used in the inhibitory test using diffusion of the disc with 5 samples in each treatment group. The sample consisted of 5 treatment groups, ethanol extract of basil leaves with concentration of $100 \%, 80 \%, 60 \%$, $40 \%$ and $20 \%$. The result of this study showed that ethanol extract of basil leaves with $100 \%$ concentration had inhibitory power of 10,26 mm (strong category), $80 \%$ of $9,65 \mathrm{~mm}$ (medium category), $60 \%$ by $8,12 \mathrm{~mm}$ (medium category), $40 \%$ by $7,33 \mathrm{~mm}$ (medium category), and $20 \%$ by $6,90 \mathrm{~mm}$ (medium category). The conclusion of this research proves that basil leaf ethanol extract has antibacterial power agains Streptococcus mutans bacteria with effective concentration is $100 \%$ with strong category equal to $10,26 \mathrm{~mm}$.
\end{abstract}

Keywords : Basil leaf, Antibacterial, and Streptococcus mutans.

\section{PENDAHULUAN}

Daun kemangi (Ocimum

basilicum L.) merupakan salah satu tumbuhan alam yang mudah diperoleh di Asia seperti Indonesia (Pramono, 2012). Herbal ini digunakan orang Asai sebagai obat dan bahan masakan dari generasi ke generasi. Minyak dari tumbuhan ini juga digunakan secara luas pada industri farmasi dan industri parfum (Wijayani, 2014).
Minyak atsiri dalam daun kemangi memiliki aktivitas antibakteri, baik bakteri gram positif maupun gram negatif, jamur dan kapang. Saat ini telah digunakan sebagai bahan pembuatan minyak wangi, lotion, sabun, sampo, atau kosmetik (Tallamma, 2014).

Permasalahan kesehatan gigi dan mulut, semakin banyak seiring perkembangan zaman. Survei yang 
dilakukan oleh Departemen Kesehatan RI. 2000, ternyata jumlah masyarakat yang berkunjung maupun yang menderita penyakit periodontal yaitu sementara 92.979 dari 858.623 pemeriksaan (Suwandi, 2012)

Streptococcus

mutans merupakan kuman yang kariogenik karena mampu segera membentuk asam dari karbohidrat yang diragikan. Kuman tersebut dapat tubuh subur dalam suasana asam dan dapat menempel pada permukaan gigi karena kemampuannya membuat polisakarida ekstra sel (Candrasari, 2012).

Karies gigi merupakan penyakit jaringan keras gigi yang masih banyak ditemukan di Indonesia pada usia anak-anak ataupun usia dewasa dengan prevalensi berkisar antara 85$99 \%$, sehingga perlu dilakukan pencegahan untuk menghambat pertumbuhan bakteri Streptococcus mutans penyebab karies gigi (Nurhidayat dkk, 2012).

Berdasarkan pertimbangan di atas, penulis merasa penting dan perlu untuk melakukan pengujian aktivitas antibakteri ekstrak etanol daun kemangi (Ocimum basilicum L.) menghambat pertumbuhan bakteri Streptococcus mutans.

\section{METODE}

Penelitian ini dilaksanakan di Laboratorium Botani, Laboratorium Kimia Organik, Laboratorium kimia Kuantitatif dan Laboratorium Mikrobiologi Fakultas Farmasi Institut Kesehatan Medistra Lubuk Pakam.

\section{Alat dan Bahan}

Alat yang digunakan adalah cawan petri, autoklaf, batang pengaduk, labu erlenmeyer, blender, inkubator, jarum ose, tabung reaksi, jangka sorong, bunsen, oven, rotary evaporator, Laminary Air Flow, neraca analitik, mikroskop, magnetic stinerr, aluminium foil, pipet mikro, pinset, krus porselin, lemari pendingin, bola karet, desikator, neraca kasar, mikro pipet, rak tabung, pipet tetes, hot plate, tissu, cotton bud, kertas cakam, rak tabung, kompor gas, erlenmeyer, gunting.

Bahan yang digunakan adalah ekstrak etanol daun kemangi (Ocimum basilicum L.), Nutrient Agar (NA), Nutrient Broth (NB), Dimetilsulfoksida $10 \%$ (DMSO), biakan bakteri Streptococcus mutans, aquadest steril, larutan etanol 96\%, $\mathrm{NaCl}$ 0,9\%.

\section{Pengambilan Bahan Tumbuhan}

Pengambilan bahan dilakukan secara purposif yaitu diambil dari satu daerah saja tanpa membandingkan dengan tanaman yang sama di daerah lain. Sampel adalah (Ocimum basilicum L.). Sampel diperoleh dari Desa Lalang, Kec. Medang Deras, Kab. Batu Bara Sumatera Utara.

\section{Pembuatan Simplisia}

Daun kemangi yang sudah dikumpulkan dibersihkan dari kotoran yang menempel dicuci dengan air yang mengalir, ditiriskan dan ditimbang berat basahnya. Setelah itu daun kemangi di anginkan di dalam ruangan terhindar dari sinar matahari hingga kering lalu ditimbang sebagai berat kering. Tujuan pengeringan yaitu untuk menghilangkan kandungan dari air yang ada didalam daun agar mencegah terjadi pertumbuhan bakteri atau jamur.

Selanjutnya dilakukan penyerbukan yaitu membuat daun kemangi menjadi partikel yang lebih kecil, disini dilakukan dengan cara diblender. Tujuan penyerbukan ini 
adalah untuk memperluas permukaan sehingga memudahkan masuknya cairan penyari kedalan sel-sel daun dan terjadi perpindahan zat aktif dari sebuk ke dalam cairan penyari, tetapi perlu dicermati untuk penyerbukan ini tidak boleh terlalu lembut karena akan meyebabkan lolos pada saat penyaringan.

\section{Pemeriksaan Karakteristik}

Pemeriksaan makroskopis dilakukan terhadap serbuk simplisia daun kemangi untuk mengamati bentuk, bau, rasa dan warna dari daun kemangi segar.

Pemeriksaan mikroskopik dilakukan terhadap daun segar dan simplisia daun kemangi. Daun kemangi segar diiris tipis secara melintang, hasil irisan daun kemangi diletakkan di kaca objek, lalu ditetesi larutan kloralhidrat, dipanaskan di atas api bunsen, ditutup dengan kaca penutup, kemudian diamati dibawah mikroskop. Serbuk simplisia ditaburkan di atas objek glass yang telah ditetesi dengan larutan kloralhidrat dan ditutup dengan kaca penutup, kemudian diamati dibawah mikroskop.

\section{Skrining Fitokimia Kandungan Metabolit Sekunder Ekstrak Etanol Daun Kemangi (Ocimum basilicum} L.).

Skirining fitokimia merupakan
tahap pendahuluan dari suatu
penelitian yang bertujuan untuk
memberikan gambaran tentang
golongan senyawa yang terkandung
dalam tumbuhan. Berdasarkan
skrining fitokimia, golongan senyawa
yang terkandung dalam ekstrak
etanol daun kemangi (Ocimum
basilicum L.) meliputi pemeriksaan
alkaloid,

steroid/triterpenoid, minyak atsiri, saponin, dan tanin. Pembuatan Ekstrak Etanol Daun
Kemangi

Pembuatan ekstrak etanol daun kemangi dilakukan dengan cara maserasi menggunakan pelarut etanol $96 \%$. Metode maserasi ini dipilih karena cara pengerjaan yang dilakukan sederhana dan alat yang digunakan mudah untuk didapatkan, serta tidak perlu pengawasan intensif. Sedangkan etanol $96 \%$ dipilih karena etanol tidak menyebabkan pembengkakan pada membran sel bakteri, selain itu berfungsi memperbaiki stabilitas zat aktif yang terlarut serta membuat zat aktif yang terbaru menjadi lebih banyak.

\section{Pembuatan Media Bakteri}

Media bakteri dibuatkan terlebih dahulu sebelum dilakukan pembiakan bakteri. Media ini berfungsi sebagai temppat untuk membiakkan bakteri yang akan diuji. Pada penelitian ini media bakteri yang dibuatkan adalah DMSO. Media yang telah dibuat kemudian disterilkan didalam autoklaf selama 15 menit pada suhu $121^{\circ} \mathrm{C}$. Setelah disterilkan media disimpan didalam kulkas. Jika akan digunakan, media dipanaskan kembali hingga mendidih lalu dituangkan kedalam cawan petri dan ditunggu sampai dingin.

\section{Uji Daya Hambat Dengan Metode Difusi Sumuran Agar (Well Diffusion Method)}

Urutan prosedur kerja untuk uji daya hambat daun kemangi adalah sebagai berikut:

a. Media agar sebanyak $15 \mathrm{ml}$ 
dituang ke dalam masingmasing cawan petri steril dan didiamkan sampai media menjadi padat selama 15 menit. Bakteri Streptococcus mutans yang telah disuspensi sebelumnya sebanyak 1 - 2 ose dari biakan murni bakteri dengan menggunakan $\mathrm{NaCl}$ $0,9 \%$ sesuai dengan standar Mc.Farland (1 x $108 \mathrm{CFU} / \mathrm{ml})$ disebar diatas medium DMSO $10 \%$ dengan menggunakan cotton bud steril lalu dilakukan usapan atau goresan secara rapat ke seluruh permukaan cawan petri.

b. Kemudian kertas cakram berukuran $7 \mathrm{~mm}$ yang telah direndam kemudian diletakan pada masing-masing cawan petri.

C. Media tersebut diinkubasi pada suhu $37^{\circ} \mathrm{C}$ selama 24 jam. Setelah itu dilakukan pengukuran diameter zona hambat dengan menggunakan jangka sorong dengan ketelitian 0,01 $\mathrm{mm}$ dan daerah zona hambat diukur sesuai metode pengukuran.

\section{Hasil}

Hasil Pemeriksaan Mikroskopik

Secara mikroskopik dari daun kemangi segar terlihat adanya: 1 . rambut penutup. 2. jaringan palisade, 3. jaringan bunga karang, 4. berkas pembuluh bentuk spiral, 5 . rambut kelenjar, dan 6. stomata tipe diastik. Hasil pemeriksaan mikroskopik dapat dilihat pada gambar 1.

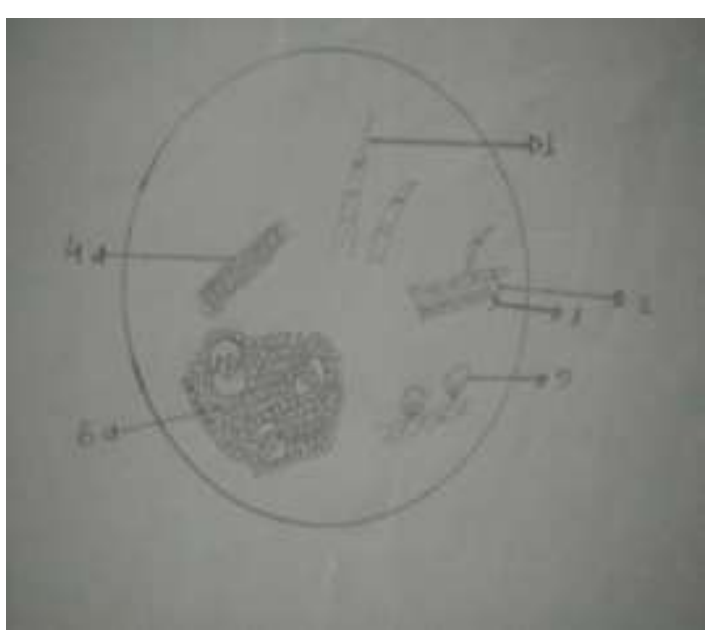

Gambar 1. Hasil Pemeriksaan Mikrokopik Daun Kemangi

\section{Hasil Karakteristik Serbuk Simplisia}

Hasil pemeriksaan kadar air, kadar sari larut air, kadar sari larut etanol, kadar abu total dapat dilihat pada tabel 1.

Tabel 1. Hasil Karakteristik Simplisia Daun Kemangi

\section{No Pemeriksaan Hasil MMI \\ (\%) (100\%)}

\begin{tabular}{llll}
\hline $\mathbf{1}$ & Kadar Air & $7,99 \%$ & $<10 \%$ \\
\hline $\mathbf{2}$ & $\begin{array}{l}\text { Kadar sari } \\
\text { larut air }\end{array}$ & $17,89 \%>8,5 \%$ \\
\hline $\mathbf{3}$ & $\begin{array}{l}\text { Kadar sari } \\
\text { larut etanol }\end{array}$ & $13,13 \%>2 \%$ \\
\hline $\mathbf{4}$ & $\begin{array}{l}\text { Kadar abu } \\
\text { total }\end{array}$ & $7,31 \% \quad<10,5 \%$
\end{tabular}

\section{Hasil Skrining Fitokimia}

Skrining fitokimia terhadap simplisia daun kemangi dilakukan untuk mendapatkan informasi golongan senyawa metabolit sekunder yang terdapat didalamnya. Hasil skrining 
fitokimia terhadap simplisia daun kemangi dapat dilihat pada tabel 2 .

Tabel 2. Hasil Skrining Serbuk Simplisia Daun Kemangi Pengaruh Ekstrak Etanol Daun Kemangi Terhadap Bakteri Streptococcus mutans

\begin{tabular}{|c|c|c|c|c|}
\hline No & $\begin{array}{l}\text { Metabolit } \\
\text { Sekunder }\end{array}$ & Pereaksi & Perubahan & Hasil \\
\hline 1 & Alkaloid & $\begin{array}{l}\text { Klorofro } \\
\text { m dan } \\
\text { meyer }\end{array}$ & $\begin{array}{l}\text { Tidak } \\
\text { terbentuk } \\
\text { endapan } \\
\text { putih }\end{array}$ & - \\
\hline 2 & Flavonoid & $\begin{array}{l}\text { Magnesiu } \\
\mathrm{m} \text { dan } \\
\mathrm{HCl}\end{array}$ & $\begin{array}{l}\text { Larutan } \\
\text { berwarna } \\
\text { kuning }\end{array}$ & + \\
\hline 3 & $\begin{array}{l}\text { Minyak } \\
\text { Atsiri }\end{array}$ & Etanol 96\% & $\begin{array}{l}\text { Adanya } \\
\text { bau khas } \\
\text { daun } \\
\text { kemangi }\end{array}$ & + \\
\hline 4 & Saponiin & Aquadest & $\begin{array}{l}\text { Todak } \\
\text { terbentuk } \\
\text { busa }\end{array}$ & - \\
\hline 5 & $\begin{array}{l}\text { Steroid/ } \\
\text { Triterpe } \\
\text { noid }\end{array}$ & $\begin{array}{l}\mathrm{CH} 3 \mathrm{COO} \\
\mathrm{H} \text { glasial }\end{array}$ & $\begin{array}{l}\text { Tidak } \\
\text { terjadi } \\
\text { perubahan } \\
\text { warna biru } \\
\text { atau } \\
\text { merah }\end{array}$ & - \\
\hline 6 & Tanin & $\begin{array}{l}\mathrm{H} 2 \mathrm{SO} 4 \\
\text { dan } \\
\mathrm{FeCl} 3 \\
5 \%\end{array}$ & $\begin{array}{l}\text { Larutan } \\
\text { berwarna } \\
\text { biru tua }\end{array}$ & - \\
\hline
\end{tabular}

Pengujian ekstrak etanol daun kemangi dilakukan dengan metode difusi yaitu menggunakan kertas cakram yang telah direndam dalam larutan ekstrak etanol daun kemangi, dengan konsetrasi $100 \%, 80 \%, 60 \%$, 40\%, $20 \%$ ekstrak etanol daun kemangi pada tiap tiap kertas cakram (Zainab, 2013). Dengan prinsip metode diameter zona beningyang terjadi disekitar kertas cakram yang dipergunakan untuk mengukur kekuatan daya hambatekstrak etanol daun kemangi terhadap mikroorganisme yang diuji. Diameter zona bening diukur dengan menggunakan jangka sorong dalam satuan millimeter. Hasil pengaruh ekstrak etanol daun kemangi terhadap bakteri Streptococcus mutans selama 24 jam. Hasil diameter zona hambat dapat dilihat pada table 3 .

Tabel 3. Rata-rata Diameter Zona Hambat Kelompok Perlakuan Setelah 24 Jam Dalam (mm

\begin{tabular}{ccc}
$\begin{array}{c}\text { Konsentrasi } \\
(\mathbf{\%})\end{array}$ & $\begin{array}{c}\text { 24 Jam } \\
(\mathbf{m m})\end{array}$ & $\begin{array}{c}\text { Respon } \\
\text { Hambat }\end{array}$ \\
\hline 20 & 6,90 & Sedang \\
\hline 40 & 7,33 & Sedang \\
\hline 60 & 8,12 & Sedang \\
\hline 80 & 9,65 & Sedang \\
\hline 100 & 10,26 & Kuat
\end{tabular}

Keterangan : ukuran zona hambat sudah termasuk ukuran kertas cakram Pengamatan dilakukan setelah media diinkubasi pada suhu $37^{\circ} \mathrm{C}$ selama 24 jam untuk melihat ada atau tidaknya pertumbuhan bakteri Streptococcus mutans yang ditandai zona hambat disekitar kertas cakram dengan menggunakan jangka sorong dengan berdasarkan penjumlahan garis horizontal dan vertikal pada bagian terluar zona bening kemudian dirata-ratakan.

Konsentrasi ekstrak etanol daun kemangi terhadap pertumbuhan bakteri Streptococcus mutans pada konsentrasi $100 \%$ memiliki rata-rata diameter zona hambat terbesar yaitu $10,26 \mathrm{~mm}$ yang termasuk katagori kuat, diikuti konsentrasi $80 \%$ sebesar $9,65 \mathrm{~mm}$ yang termasuk katagori sedang, diikuti konsentrasi $60 \%$ sebesar $8,12 \mathrm{~mm}$ yang termasuk katagori sedang, Konsentrasi 40\% sebesar $7,3 \mathrm{~mm}$ yang termasuk kategori sedang dan konsentrasi $20 \% \$$ sebesar $6,90 \mathrm{~mm}$ yang termasuk kategori sedang.

\section{PEMBAHASAN}


Dari hasil penelitian uji aktivitas antibakteri ekstrak etanol daun kemangi (Ocimum basilicum L.) terhadap pertumbuhan bakteri Streptococcus mutans didapatkan bahwa semua konsentrasi ekstrak etanol daun kemangi memiliki efek terhadap bakteri Streptococcus mutans. Etanol merupakan senyawa turunan alkohol yang memiliki sifat antibakteri yang merupakan pelarut yang umumnya digunakan untuk mengekstraksi kandungan kimia tanaman yang berupa komponen aktif (komponen organik) sebagai antimikroba (Zainab, 2013).

Hasil penelitian dapat dilihat setelah 5 lembar kertas cakram direndam kedalam cawan petri yang berisi sediaan konsentrasi $100 \%$, 80\%, $60 \%$, 40\%, 20\% ekstrak etanol daun kemangi. Kertas cakram diletakkan pada media Natrium Agar (NA) yang telah diinokulasi suspensi bakteri Streptococcus mutans. Pengamatan dilakukan setelah media diinkubasi pada suhu $37^{\circ} \mathrm{C}$ selama 24 jam untuk melihat ada atau tidaknya pertumbuhan bakteri Streptococcus mutans yang ditandai zona hambat disekitar kertas cakram dengan menggunakan jangka sorong dengan berdasarkan penjumlahan garis horizontal dan vertikal pada bagian terluar zona bening kemudian dirataratakan.

Kertas cakram yang telah diredam dalam ekstrak etanol daun kemangi yang diletakkan diatas media NA yang sebelumnya telah disuspensikan dengan bakteri Streptococcus mutans. Media tersebut diinkubasi selama 24 jam pada suhu $37^{\circ} \mathrm{C}$ dan dilihat pertumbuhan bakteri yang ditandai dengan adanya zona hambat disekitar kertas cakram. Hasil kertas cakram yang direndam dalam ekstrak dapat dilihat pada gambar 2.

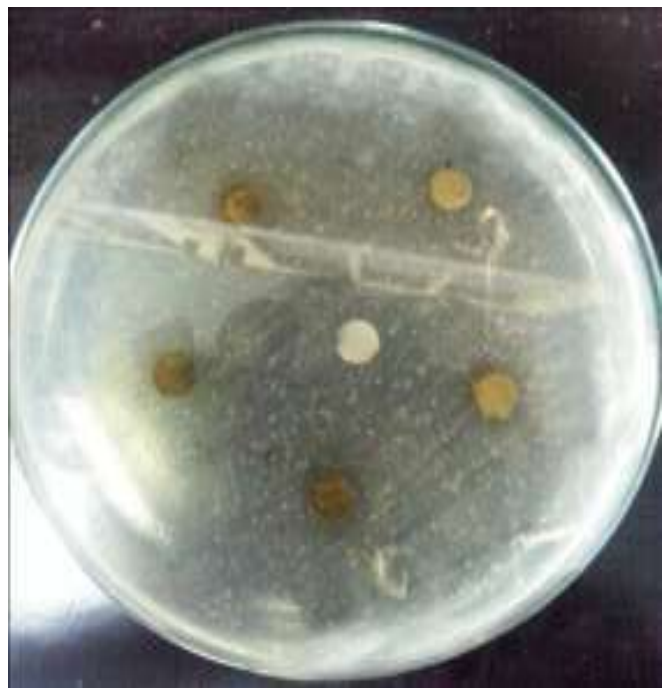

Gambar 2. Kertas Cakram Yang Direndam Kedalam Media

Zona hambat disekitar kertas cakram pada berbagai konsentrasi setelah diinkubasi selama 24 jam pada suhu $37^{\circ} \mathrm{C}$. Perhitungan besarnya zona hambat terbesar pada ekstrak etanol daun kemangi adalah pada konsentrasi $100 \%$ dengan menggunakan jangka sorong sebesar 10,26 mm. Hasil zona hambat pada ekstrak etanol daun kemangi dapat dilihat paga gambar 3 .

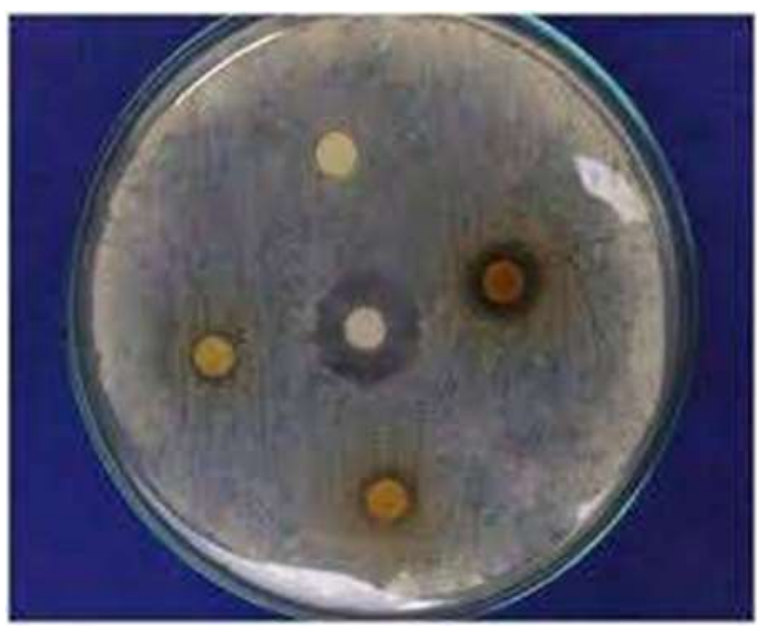

Gambar 3. Perhitungan Besar Zona Hambat Pada Kertas Cakram 


\section{KESIMPULAN}

Dari hasil penelitian uji aktivitas antibakteri ekstrak etanol daun kemangi terhadap pertumbuhan bakteri Streptococcus mutans tahun 2018 dapat disimpulkan bahwa:

1. Ekstrak daun kemangi memiliki efek antibakteri terhadap bakteri Streptococcus mutans pada konsentrasi $100 \%, 80 \%$, $60 \%, 40 \%$ dan $20 \%$.

2. Ekstrak etanol daun kemangi dapat mempengaruhi pertumbuhan bakteri Streptococcus mutans dengan berbagai konsentrasi.

3. Ekstrak etanol daun kemangi (Ocimum basilicum L.) memiliki aktivitas antibakteri terhadap bakteri Streptococcus mutans.

4. Konsentrasi ekstrak etanol daun kemangi yang paling efektif dalam membentuk aktivitas antibakteri terbaik merupakan konsentrasi $100 \%$ yang mempunyai daya hambat sebesar 10,26 mm.

\section{Saran}

1. Perlu dilakukan penelitian mengenai kemampuan ekstrak etanol daun kemangi dalam menghambat perteumnuhan bakteri Streptocpccus mutans dengan konsentrasi yang berbeda dan dengan sampel yang lebih banyak.

2. Perlu dilakukan penelitian lebih lanjut mengenai kemampuan ekstrak daun kemangi apabila diaplikasikan sebagai bahan

3. pasta gigi dan antiseptic rongga mulut.

\section{DAFTAR PUSTAKA \\ Buku :}

Pranomo, 2012. Atlas Tumbuhan Obat Indonesia. Setiawan Dalimartha Publication. Jakarta.

\section{Jurnal :}

Candrasari, Anika. (2012). Uji Daya Antimikroba Ekstrak Etanol Daun Sirih Merah (Piper Crocatum ruiz \& Pav.) Terhadap Pertumbuhan Staphylococcus Aureus ATCC 6538, Eschericia Coli ATCC 11229 dan Candida Albicans ATCC 10231 Secara In Vitro. Fakultas Kedokteran Universitas Muhammadiyah. Surakarta.

Departemen Kesehatan RI. 2000. Pedoman Pelaksanaan Usaha Kesehatan Gigi Sekolah. Direktorat Jendral Pelayanan Medik, Direktorat Kesehatan Gigi : Jakarta.

Suwandi, T. (2012). Pengembangan Potensi Antibakteri KelopakBunga Hibiscus Sabdariffa L. (Rosela) Terhadap Streptococcus Sanguinis Penginduksi Gingivitis Menuju Obat Herbal Terstandart. Disertasi, Program Dokter Ilmu Kedokteran Gigi Universitas Indonesia.

Tallamma, F. (2014). Efektivita Ekstrak Daun Kemangi (Ocimum basilicum L.) Terhadap Penurunan Kadar Volatile Sulfur Compounds (VSCs). Fakultas Kedokteran Gigi Universitas Hasanuddin. Makasar.

Wijayani, L. A, (2014). Efek Larvasidal Ekstrak Etanol Daun Kemangi (Ocimum sp. Linn) Terhadap Larva Instar III Culex quinquefasciatus. Universitas Islam Indonesia, Jakarta. 
Zainab (2013). Pengaruh Konsentrasi Etanol Sebagai Pelarut Pengekstraksi Terhadap Naftokinon dalam Ekstrak Daun Pacar Kuku (Lawsonia inermis L.). Jurnal Pharmaciana, Vol. 3, No. 2.

\section{Artikel Online :}

Nurhidayat, O., Eram, T. \& Bambang, W. (2012). Perbandingan Media Power Point Dengan Flip Chart Dalam Meningkatkan Pengetahuan Kesehatan Gigi dan Mulut, (Online)

(http://journal.unnes.ac.id/sju/inde x,php/ujph). Diakses 20 Maret 2020. 